\title{
PALYNOLOGICAL ORIGIN, PHENOLIC CONTENT AND ANTIOXIDANT PROPERTIES OF GEOPROPOLIS COLLECTED BY MANDAÇAIA (MELIPONA MANDACAIA) STINGLESS ${ }^{1}$
}

\author{
PAULO RICARDO DA SILVA ${ }^{2}$, TELMA MARIA GUEDES DA SILVA ${ }^{2}$, CELSO AMORIM CAMARA $^{2}$, EVA \\ MÔNICA SARMENTO DA SILVA ${ }^{3}$, FRANCISCO DE ASSIS RIBEIRO DOS SANTOS ${ }^{4}$, TANIA MARIA SARMENTO \\ SILVA $^{2 *}$
}

\begin{abstract}
The stingless bee Melipona mandacaia (Smith 1863) (mandaçaia) is found only in the region of Caatinga, Northeastern Brazil, in the states of Bahia and Pernambuco, near to São Francisco river. The aim of the present work was to determine the botanical origin and to evaluate the phenolic content and antioxidant properties ( $\beta$-carotene/linoleic acid system, DPPH and ABTS scavenging) of mandaçaia geopropolis. 25 pollen types from 15 families were identified from the 9 geopropolis samples analyzed. Phenolic compounds content varied between all the geopropolis EtOH extracts, hexane, EtOAc and MeOH: $\mathrm{H}_{2} \mathrm{O}$ fractions. The main pollens found in the geopropolis samples were from the Leguminoseae family. This identification of meliponicultural plants is extremely important because it indicates the food sources used for the collection of nectar and pollen. Our results revealed that there is a strong relation between the phenolic compounds and the antioxidant activity. These results showed that total phenols of mandaçaia geopropolis may be responsible for the antioxidant activity with evidence that it's a rich source of phenols bioactive compounds with potential health benefits.
\end{abstract}

Keywords: Melipona mandacaia. Geopropolis. Phenolic. Antioxidant.

\section{ORIGEM PALINOLÓGICA, CONTEÚDO FENÓLICO E PROPRIEDADES ANTIOXIDANTES DE GEOPROPOLIS COLETADAS POR MANDAÇAIA (MELIPONA MANDACAIA) STINGLESS}

RESUMO - A abelha sem ferrão Melipona mandacaia (Smith 1863) (mandaçaia) é encontrada apenas na região da Caatinga, Nordeste do Brasil, nos estados da Bahia e Pernambuco, próximo ao rio São Francisco. O objetivo do presente trabalho foi determinar a origem botânica e avaliar o conteúdo fenólico e as propriedades antioxidantes (sistema $\beta$-caroteno / ácido linoléico, DPPH e sequestro do ABTS) da geopropolis da mandaçaia. Foram identificados 25 tipos polínicos de 15 famílias das 9 amostras de geoprópolis analisadas. $\mathrm{O}$ teor de compostos fenólicos variou entre todos os extratos etanólicos e as frações hexano, EtOAc e $\mathrm{MeOH}: \mathrm{H}_{2} \mathrm{O}$ de geoprópolis. Os principais polens encontrados nas amostram de geopropolis foram da família Leguminoseae. Esta identificação de plantas utilizadas pelas meliponas indicam a importancia destas espécies vegetais como fontes de nectar e pólen. Nossos resultados revelaram que existe uma forte relação entre os compostos fenólicos e a atividade antioxidante. Estes resultados mostram que os fenóis totais da geoprópolis de mandaçaia foram responsáveis pela atividade antioxidante, com evidências de que é uma fonte rica de compostos bioativos fenólicos com potenciais benefícios a saúde.

Palavras-chave: Melipona mandacaia. Geoprópolis. Fenólicos. Antioxidante.

\footnotetext{
${ }^{*}$ Corresponding author

${ }^{1}$ Received for publication in $08 / 08 / 2019$; accepted in $01 / 20 / 2020$.

Paper extracted from the doctoral thesis of the first author.

${ }^{2}$ Phytochemical Bioprospecting Laboratory, Department of Chemistry, Universidade Federal Rural de Pernambuco, Recife, PE, Brazil; pauloricardoifpe@gmail.com - ORCID: 0000-0002-7231-4602, guedes.meira@gmail.com - ORCID: 0000-0001-5778-0384, ccelso@ufrpe.br - ORCID: 0000-0001-8748-8560, sarmentosilva@gmail.com - ORCID: 0000-0003-1887-2598.

${ }^{3}$ Zootechnics Collegiate, Universidade Federal do Vale do São Francisco, Petrolina, PE, Brazil; evasarmento@yahoo.com.br, - ORCID: 0000-0002-0860-2925.

${ }^{4}$ Plant Micromorphology Laboratory, Department of Biological Sciences, Universidade Estadual de Feira de Santana, Feira de Santana, BA, Brazil; f.a.r.santos@gmail.com - ORCID: 0000-0002-9246-3146.
} 


\section{INTRODUÇÃO}

Meliponiculture is known as breeding of indigenous stingless bees. This activity, generally undertaken by traditional communities, has local characteristics according to regional and traditional knowledge. The honey produced by these bees is used as a source of food and medicine and, in some cases, represents an important improvement in family income. The primary importance of this species is associated with environmental conservation and fruit production, as they pollinate wild plants and cultivated crops in the semiarid Caatinga (shrub vegetation) and humid preAmazonian forest regions (SILVA et al., 2006). The stingless bee Melipona mandacaia (Smith 1863) (mandaçaia) is found only in the region of Caatinga, Northeastern Brazil, in the states of Bahia and Pernambuco, near to São Francisco river. These bees are important for pollination of many plants of the Caatinga and produce a tasty honey bee commercially valuable. Besides the honey bee, the mandaçaia produces geopropolis that is a special type of propolis, or bee glue, that is a mixture of plant resins and waxes and earth (BARTH; LUZ, 2003).

The pollen spectrum present in propolis/ geopropolis contains pollen grains brought by bees and also pollen grains which are brought by wind (anemophilous) and adhered to the resin. Thus, pollen analysis is a valuable tool for the verification and labeling of samples of this apicultural product, since it allows for the determination of their geographical origin, indicating the different regions of production and the season in which they were made (BARTH 1998; MATOS; ALENCAR; SANTOS, 2014).

In recent years, studies investigating the geopropolis produced by Melipona bees have reported the presence of prenylated benzophenones (TOMÁS-BARBERÁN et al., 1993), phenolic compounds (BANKOVA; CASTRO; MARCUCCI, 2000; SOUZA et al., 2013, 2018; DUTRA et al., 2014; SOUZA JUNIOR et al., 2019), di- and triterpenes and gallic acid (VELIKOVA et al., 2000). The samples of geopropolis has been shown to exhibit antimicrobial activity, as well as antioxidant (DUTRA et al. 2014; SOUZA et al., 2013; SOUZA JUNIOR et al., 2019), anti-inflammatory, antinociceptive and antiproliferative properties (FRANCHIN et al., 2012; CUNHA et al., 2013).

Oxidative stress is thought to contribute to the development of chronic and degenerative diseases, such as cancer, autoimmune disorders, aging, cataract, rheumatoid arthritis, and cardiovascular and neurodegenerative diseases. The antioxidant property of geopropolis due to its high concentration of phenolics and other antioxidant compounds (SOUZA et al., 2013; DUTRA et al., 2014), may be a potential supplement for preventing chronic degeneration diseases.

The aim of the present work is to determine the botanical origin and to evaluate the phenolic content and antioxidant properties of mandaçaia geopropolis from two semi-arid regions in the state of Bahia and Pernambuco, Brazil.

\section{MATERIAL AND METHODS}

\section{Geopropolis samples and fractionation}

The nine samples of geopropolis were collected at two semi-arid regions in the state of Bahia and Pernambuco, Brazil. The samples 01 (March 2012), 03, 04 and 05 (April 2012) were collected in municipality of Juazeiro, Bahia $\left(9^{\circ}\right.$ 24'58.4"S 40³1'24.5"W) and samples 02 (April 2012), 06 (March 2013), 07 (May 2013), 08 (June 2013) and 09 (October 2013) were collected at campus of Universidade Federal do Vale do São Francisco (UNIVASF), municipality of Petrolina, Pernambuco $\quad\left(9^{\circ} 19^{\prime} 26^{\prime \prime S} \quad 40^{\circ} 33^{\prime} 36^{\prime \prime W}\right)$. The geopropolis (4.9-50.4 g) were extracted with ethanol in an ultrasonic water bath. The combined ethanol extracts were completely evaporated under reduced pressure to afford a brown residue. $2 \mathrm{~g}$ of the ethanol extracts were suspended in $\mathrm{MeOH}: \mathrm{H} 2 \mathrm{O}$ and partitioned with hexane and ethyl acetate to yield the corresponding soluble fractions, yielding hexane (795.2-1137.4 mg), ethyl acetate (700.6-994.0 mg) and $\mathrm{MeOH}: \mathrm{H} 2 \mathrm{O}$ (7.9-30.4 mg) fractions.

\section{Pollen analysis}

To analyze pollen grains from geopropolis, the methodology of Matos; Alencar and Santos (2014) were used. Thus geopropolis samples (c. 5 g) were grounded and stored in EtOH (95\%) for 24 hours. Preparations were centrifuged (10 $\mathrm{min}, 2.500$ $\mathrm{rpm})$ in order to gather solid residues. Sediments were treated by $\mathrm{KOH}$ solution $10 \%(20 \mathrm{~mL})$, boiling for $10 \mathrm{~min}$. At room temperature, preparations were centrifuged in order to concentrated solid residues; glacial acetic acid $(30 \mathrm{~mL})$ was added to dehydrate for a period up to 24 hours. After centrifugation, sediments were treated by acetolysis methodology (ERDTMAN, 1960). Sediments contenting pollen grains were mounted on slides with glycerin jelly after washed with distilled water, and rest in aqueous glycerin $(50 \%)$ for two hours. Pollen grains on preparation were counted and their botanical affinity set according Santos (2011) recommendations.

\section{Determination of the total phenolic content}

The total phenolic content of the samples was determined with the Folin Ciocalteu reagent, according to the method of Slinkard and Singleton (1977) that was modified using gallic acid as a 
standard phenolic compound. $100 \mu \mathrm{L}$ of $\mathrm{EtOH}$ extracts and hexane, EtOAc and $\mathrm{MeOH}: \mathrm{H}_{2} \mathrm{O}$ fractions $(1 \mathrm{mg} / \mathrm{mL})$ were transferred to an Eppendorff $1 \mathrm{~mL}$ vial. Folin Ciocalteu reagent (20 $\mu \mathrm{L})$ and $820 \mu \mathrm{L}$ of distilled water were added and the contents of the flask were mixed thoroughly. After $1 \mathrm{~min}, 60 \mu \mathrm{L}$ of sodium carbonate $(15 \%)$ was added and then the mixture allowed to stand for $2 \mathrm{~h}$. The absorbance was measured at $760 \mathrm{~nm}$ in a spectrophotometer (ELISA). The amount of total phenolic compounds was determined in micrograms of gallic acid equivalent using the equation obtained from the standard gallic acid graph.

\section{Dpph $^{\bullet}$ radical scavenging assay}

The free radical-scavenger activity was determined using the DPPH assay, as described previously (SILVA et al., 2006) with modifications. The antiradical activity was evaluated using a dilution series to obtain five concentrations (1$100 \mu \mathrm{g} / \mu \mathrm{L})$. This process involved mixing the DPPH solution $(23.6 \mu \mathrm{g} / \mathrm{mL}$ in ethanol) with an appropriate EtOH extracts, hexane, EtOAc and $\mathrm{MeOH}: \mathrm{H}_{2} \mathrm{O}$ fractions followed by homogenization. After $30 \mathrm{~min}$, the remaining DPPH radicals were quantified by measuring the absorption at $517 \mathrm{~nm}$ using an automatic Biochrom Asys UVM 340 microplate reader (Cambridge, UK). The percentage of inhibition was given by the formula: percent inhibition $(\%)=[(\mathrm{A} 0-\mathrm{A} 1) / \mathrm{A} 0] \times 100$, where $\mathrm{A} 0$ was the absorbance of the control solution and A1 was the absorbance in the presence of the sample and standards.

\section{$\mathrm{Abts}^{\bullet+}$ radical cation decolorization assay}

The radical cation decolorization assay was based on the method described by Re et al. (1999) with modifications. ABTS was dissolved in water to yield a final concentration of $7 \mathrm{mM}$. The ABTS radical cation $\left(\mathrm{ABTS}^{\bullet+}\right.$ ) was produced by reacting the ABTS stock solution with $2.45 \mathrm{mM}$ potassium persulfate (final concentration) and allowing the mixture to stand in the dark at room temperature for $16 \mathrm{~h}$ before use. The $\mathrm{ABTS}^{\bullet+}$ solution was diluted to give an absorbance of $0.70 \pm 0.05$ at $734 \mathrm{~nm}$ with ethanol before use with an automatic Biochrom Asys UVM 340 microplate reader (Cambridge, UK). Then, appropriate amounts of the $\mathrm{ABTS}^{\bullet+}$ solution were added into $0.5 \mathrm{~mL}$ of the sample solutions in ethanol at five concentrations $(1-100 \mu \mathrm{g} / \mathrm{mL})$. After $10 \mathrm{~min}$, the percentage inhibition of absorbance at $734 \mathrm{~nm}$ was calculated for each concentration, which was relative to the blank absorbance (ethanol). The capability to scavenge the $\mathrm{ABTS}^{\bullet+}$ radical was calculated using the following equation: $\mathrm{ABTS}^{\bullet+}$ scavenging effect $(\%)=[(\mathrm{A} 0-\mathrm{A} 1 / \mathrm{A} 0) \times 100]$, where $\mathrm{A} 0$ is the initial concentration of the $\mathrm{ABTS}^{\bullet+}$ and A1 is absorbance of the remaining concentration of
$\mathrm{ABTS}^{\bullet+}$ in the presence of sample.

\section{B-carotene bleaching (bcb) assay}

The antioxidant activity of the EtOH extracts and hexane, EtOAc and $\mathrm{MeOH}: \mathrm{H}_{2} \mathrm{O}$ fractions were evaluated by the $\beta$-carotene linoleate model system, as described by Emmons; Peterson and Paul (1999) with some modifications. $\beta$-Carotene $(20 \mathrm{mg})$ was dissolved in $1 \mathrm{~mL}$ of chloroform and $50 \mu \mathrm{L}$ was added to $80.0 \mu \mathrm{L}$ of linoleic acid and $660.0 \mu \mathrm{L}$ of Tween 20. Oxygenated deionized water $(140 \mathrm{~mL})$ was added and the solution was thoroughly mixed. Aliquots of $3 \mathrm{~mL}$ of the carotene/linoleic acid emulsion were mixed with samples of EtOH extracts, hexane, EtOAc and $\mathrm{MeOH}: \mathrm{H}_{2} \mathrm{O}$ fractions of geopropolis $(20.0$ and $40.0 \mu \mathrm{g} / \mathrm{mL})$ and incubated in a water bath at $40^{\circ} \mathrm{C}$. The emulsion oxidation was monitored spectroscopically by measuring the absorbance at $470 \mathrm{~nm}$ over a period of $60 \mathrm{~min}$. The control sample contained solvent in place of the extract. The antioxidant activity was expressed as the percentage of inhibition relative to the control after a 60 min incubation period using the following equation: $\mathrm{AA}=100(\mathrm{DRC}-\mathrm{DRS}) / \mathrm{DRC}$. Where AA is the antioxidant activity, DRC is the degradation rate in the presence of the control (=Absi-Absf), DRS is the degradation rate in the presence of the sample (=Absi-Absf), Absi is the initial absorbance at time 0 and Abf is the absorbance at 20, 40,60 and $80 \mathrm{~min}$. Trolox (a water-soluble Vitamin E analog) at a concentration of $16 \mu \mathrm{g} / \mathrm{mL}$ was used as the reference antioxidant.

\section{Statistical analysis}

All analyses were performed in triplicate. The results were expressed as the mean \pm standard deviation and were analyzed using the GraphPad Prism 5.0 program (DEMO). Significance was accepted when the $p$ value was $\leq 0.05$. Pearson's correlation test was used to evaluate the correlations. One-way analysis of variance (ANOVA) and Tukey's multiple-comparisons test were used to determine significant differences between means.

\section{RESULTS AND DISCUSSION}

Results from the qualitative pollen analysis for the 1-9 mandaçaia geopropolis samples are summarized in Table 1. All results are listed as percentages of the total pollen content in each sample. Overall, 25 pollen types from 15 families were identified from the 9 geopropolis samples analyzed. Senna (Leguminoseae) was the predominant pollen type in 8 of the 9 geopropolis. This pollen type was present in a total of 8 samples, which represents a minimum of $3.2 \%$ to a maximum of $50.0 \%$ of total pollen. Senna species are very 
common plant species in the Caatinga region and its presence in mandaçaia geopropolis in large amounts is expected. Sample 7 showed only two types of pollen in the proportion of $50 \%$ of each species Senna and Malphigia. Mimosa was the second most abundant pollen type identified present in six samples and was the predominant pollen in sample 06. Species of this genus is also common is Caatinga. Matos; Alencar and Santos (2014) analyzed twentytwo propolis samples produced by Apis mellifera L. in an area of the Semiarid region the State of Bahia and verified that the pollen type Mimosa pudica was highly representative and was identified in all samples analyzed as indicative of a possible propolis source. It is a very common invasive species, occurring frequently in degraded areas and roadsides. Pollen grains from a number of other species were present in a large number of the geopropolis samples, although at generally lower levels. A number of specific plant varieties similarly represented were also present in the 9 geopropolis, at levels ranging from $3.00 \%$ to $42.86 \%$ of total pollen grains. All of these are relatively common plants in Caatinga. In samples 3, 7, 8 and 9 were verified five pollen type indeterminate. The pollen types that occur at low frequency in geopropolis samples can be regarded as reference of the botanicals species supplying resin and are important indicators of the flora of Caatinga region (MATOS; ALENCAR; SANTOS, 2014). This extensive availability of plants with high pollen productivity makes this a species of high meliponicultural potential.

The pollen spectra of the nine geopropolis samples studied reflect a vegetation characteristic of the Northeast region of Brazil, near the river São Francisco. The identification of meliponicultural plants is extremely important because it indicates the food sources used for the collection of nectar and pollen. It's very important also to maintenance of natural vegetation. The results presented are the basis for future studies, in order to provide means for the certification of this meliponicultural product.

Table 1. Palynological analysis of bee mandaçaia (Melipona mandacaia) geopropolis samples.

\begin{tabular}{|c|c|c|c|c|c|c|c|c|c|c|}
\hline \multirow[t]{2}{*}{ Family } & \multirow[t]{2}{*}{ Botanical origin } & \multicolumn{9}{|c|}{$\%$ Frequency } \\
\hline & & 01 & 02 & 03 & 04 & 05 & 06 & 07 & 08 & 09 \\
\hline Amaranthaceae & Alternanthera & - & 4.76 & - & 3.20 & - & - & 6.25 & - & - \\
\hline Anacardiaceae & Anacardiaceae & - & - & - & - & - & 14.29 & - & - & 7.14 \\
\hline Arecaceae & Arecaceae & - & - & - & - & - & - & 6.25 & - & - \\
\hline Asteraceae & Vernonia & - & - & - & - & - & - & 6.25 & 3.33 & - \\
\hline Boraginaceae & Cordia & - & - & 10.00 & - & - & - & - & - & - \\
\hline Caryophyllaceae & Caryphyllaceae & 12.50 & 4.76 & - & 6.45 & - & - & - & - & 14.29 \\
\hline Cecropiaceae & Cecropia & - & - & - & 3.20 & - & - & - & - & - \\
\hline Commelinaceae & Combretaceae & - & - & - & 3.20 & - & - & - & - & - \\
\hline Convolvulaceae & Ipomoea & - & - & - & - & - & - & - & 3.33 & - \\
\hline \multirow[t]{7}{*}{ Leguminosae } & Amburana & - & - & - & 3.33 & - & - & - & - & - \\
\hline & Chamaecrista & 37.50 & - & - & - & - & 14.29 & - & - & - \\
\hline & Mimosa & - & 14.28 & - & 6.45 & - & 42.84 & 12.5 & 13.33 & 14.29 \\
\hline & Parapiptadenia & 12.50 & 4.76 & - & 9.70 & - & - & - & 3.33 & - \\
\hline & Pithecelobium & - & - & - & - & - & - & - & - & - \\
\hline & Poincianella & - & 42.86 & - & 29.15 & - & - & - & 3.33 & - \\
\hline & Senna & 12.50 & 14.28 & 20.00 & 3.20 & 50.00 & 14.29 & 18.75 & 23.33 & - \\
\hline Malpighiaceae & Malpighia & - & - & 10.00 & 12.90 & 50.00 & 14.29 & - & - & 7.14 \\
\hline Malvaceae & Sida & - & - & - & 3.20 & - & - & - & - & - \\
\hline \multirow[t]{2}{*}{ Myrtaceae } & Myrtaceae & 12.50 & 9.54 & 30.00 & 9.70 & - & - & - & 3.33 & 7.14 \\
\hline & Psidium & - & - & 20 & - & - & - & - & - & - \\
\hline Poaceae & Poaceae & - & 4.76 & - & 6.45 & - & - & 25.00 & - & 7.14 \\
\hline \multirow[t]{4}{*}{ Rubiaceae } & Borreria & - & - & - & - & - & - & - & - & 7.14 \\
\hline & Faramea & - & - & - & - & - & - & - & - & 14.29 \\
\hline & Mitracarpus & - & - & - & - & - & - & - & - & - \\
\hline & Richardia & 12.50 & - & - & - & - & - & - & - & - \\
\hline \multirow[t]{5}{*}{ Undetermined } & Undet 1 & - & - & - & - & - & - & 6.25 & 10.05 & - \\
\hline & Undet 2 & - & - & 10.00 & - & - & - & - & - & 7.14 \\
\hline & Undet 3 & - & - & - & - & - & - & - & 36.64 & 14.29 \\
\hline & Undet 4 & - & - & - & - & - & - & 6.25 & - & - \\
\hline & Undet 5 & - & - & - & - & - & - & 12.50 & - & - \\
\hline Total & & 100.0 & 100.0 & 100.0 & 100.0 & 100.0 & 100.0 & 100.0 & 100.0 & 100.0 \\
\hline
\end{tabular}


The results obtained showed that the phenolic compounds content varied between all the geopropolis EtOH extracts (42.41-213 mg GAE/g), hexane (17.50-41.39 mg GAE/g), EtOAc (51.29$290.55 \mathrm{mg}$ GAE/g) and $\mathrm{MeOH}: \mathrm{H}_{2} \mathrm{O}(30.19-289.81$ mg GAE/g) fractions (Table 2). There were significant differences, using the Tukey test $(\mathrm{p}<$ 0.05 ), between total phenolic compound values obtained for the nine geopropolis samples. With the exception of the samples 7-9 all EtOAc fractions showed higher total phenolic content and the hexane fractions with a lesser amount.

Our results agreed with the ones obtained by Souza et al. (2013) in geopropolis of jandaira (Melipona subnitida) and geopropolis produced by Melipona fasciculata (DUTRA et al., 2014). These samples showed that the EtOAc fractions presents higher total phenolic content.

The geopropolis shows characteristic amounts of total polyphenols due to its botanical and geographical origin. This situation can explain the observed differences between the samples in this study. Although the samples have been collected near São Francisco river, semiarid region of Northeastern, the difference in the amount of phenolic compounds may be related to several factors such as weather, time of collection and especially the vegetation near the hive of bees. Other studies are needed to identify what the phenolic compounds present in geopropolis of mandaçaia.

Antioxidants have attracted much interest because of their protective effect against free radical damage, which is the cause of many diseases, including cancer. Three different methods were used to determine the antioxidant properties of the geopropolis, which allowed us to obtain information about the activity of these extracts during the different stages of the oxidation reaction (PRIOR; WU; SCHAICH, 2005). The methods used included the inhibition of $\beta$-carotene, cooxidation in a linoleic acid model system, DPPH and ABTS scavenging.

The results of the DPPH radical scavenging activity of the different geopropolis samples are summarized in Table 2. The highest effective geopropolis was $\mathrm{MeOH}: \mathrm{H}_{2} \mathrm{O}$ fractions. The hexane fractions were inactive. The results showed that geopropolis from two different regions of semiarid differed significantly $(\mathrm{p}<0.05)$ in their $\mathrm{EC}_{50}$ of $\mathrm{DPPH}$ radical scavenging in the EtOH extracts, EtOAc and $\mathrm{MeOH}: \mathrm{H}_{2} \mathrm{O}$ fractions. Our results were different also to the data by Souza et al. (2013). These authors found that the EtOAc fractions were more actives. The antioxidant activity of this natural product was attributed to the phenolic compounds isolated from this fraction: 6-O-p-coumaroyl- $D$ galactopyranose, 6 - $O$-cinnamoyl-1- $O-p$-coumaroyl- $\beta$
-D-glucopyranose, 7-O-methyl naringenin, 7-Omethyl aromadendrin, 7,4'-di- $O$-methyl aromadendrin, 4'-O-methyl kaempferol, 3-O-methyl quercetin, 5-O-methyl aromadendrin and 5-O-methyl kaempferol that have free radical scavenging properties. Comparing the results of this study with values obtained for the geopropolis colleted by Melipona fasciculata (DUTRA et al., 2014) is possible observe that the hexane fraction was inactive in two samples and the activities of EtOH extracts, EtOAc and $\mathrm{MeOH}: \mathrm{H}_{2} \mathrm{O}$ fractions were differents.

In the ABTS assay, the EtOAc and $\mathrm{MeOH}: \mathrm{H}_{2} \mathrm{O}$ fractions, which contained the highest levels of phenolic compounds, exhibited the lowest $\mathrm{CE}_{50}$ value, was observed free radical scavenging to hexane fraction, with $\mathrm{CE}_{50}$ ranged $67.36 \pm 0.58$ to $100.14 \pm 0.73 \mu \mathrm{g} / \mathrm{mL}$ (Table 2). Overall the free radical scavenging activity against ABTS of extracts and fractions of geopropolis was better than for the $\mathrm{DPPH}$ radical. The results to values of $\mathrm{EC}_{50}$ to extracts and fractions showed significant differences $(\mathrm{p}<0.05)$. The differences in antioxidant activity between the same samples demonstrated by the different assays, can be explained by the reaction mechanisms of the methods. Dutra et al. (2014) also showed that extracts obtained of Melipona fasciculata geopropolis have better radical scavenging to ABTS as compared to DPPH, except to hexane extract that was inactive.

The results obtained to $\beta$-carotene/linoleic acid system ( $\mathrm{t}=60 \mathrm{~min})$ with the geopropolis extracts and fractions are presented in Table 2. Our data indicated a better antioxidant capacity to EtOH extracts and EtOAc fractions. In this test significant differences $(p<0.05)$ were observed between same sample of nine analysed bee geopropolis (Table 2). Comparing the results of this study with values obtained in studies concerning jandaira geopropolis (SOUZA et al., 2013), it is possible to observe that the data for to antioxidant activity are better for mandaçaia geopropolis for all extracts and fractions. However, different samples exhibited varying degrees of antioxidant capacity. The results revealed that there is an strong relation between the phenolic compounds and the antioxidant activity.

These results suggest that total phenols of mandaçaia geopropolis were responsible for the antioxidant activity. The correlations between the results of the DPPH, ABTS and antioxidant methods and total phenolic content are shown in Table 3 with evidence that geopropolis is a rich source of bioactive compounds with potential health benefits. Further studies are needed to identify the phenolic compounds present in mandaçaia geopropolis. 
P. R. SILVA et al.

Table 2. Total phenolic and antioxidant activity of mandaçaia geopropolis samples.

\begin{tabular}{|c|c|c|c|c|c|c|c|c|}
\hline \multirow[b]{2}{*}{ Sample } & \multicolumn{4}{|c|}{ Total phenolic content $(\mathrm{mg} \mathrm{GAE} / \mathrm{g} \pm \mathrm{SD})^{\mathrm{a}, *}$} & \multicolumn{4}{|c|}{$\mathrm{DPPH}\left(\mathrm{EC}_{50}\right)^{\mathrm{a}, \mathrm{b}^{*}} \mu \mathrm{g} / \mathrm{mL}$} \\
\hline & $\mathrm{EtOH}$ & Hexane & EtOAc & $\mathrm{MeOH}: \mathrm{H}_{2} \mathrm{O}$ & $\mathrm{EtOH}$ & Hexane $^{c}$ & EtOAc & $\mathrm{MeOH}: \mathrm{H}_{2} \mathrm{O}$ \\
\hline 1 & $43.21 \pm 2.77$ & $22.96 \pm 2.40$ & $137.96 \pm 5.94$ & $125.93 . \pm 7.45$ & $49.80 \pm 0.54$ & - & $83.44 \pm 0.44$ & $33.25 \pm 0.56$ \\
\hline 2 & $96.67 \pm 2.80$ & $17.50 \pm 2.67$ & $290.55 \pm 4.24$ & $289.81 \pm 3.24$ & $32.01 \pm 0.34$ & - & $50.97 \pm 0.46$ & $6.95 \pm 0.08$ \\
\hline 3 & $42.41 \pm 6.12$ & $37.78 \pm 3.94$ & $168.79 \pm 2.60$ & $52.31 \pm 4.42$ & $54.15 \pm 0.81$ & - & $54.15 \pm 0.35$ & $57.85 \pm 0.30$ \\
\hline 4 & $213.89 \pm 5.56$ & $34.63 \pm 1.04$ & $191.09 \pm 4.35$ & $67.59 \pm 1.67$ & $10.73 \pm 0.06$ & - & $48.87 \pm 0.50$ & $16.09 \pm 0.27$ \\
\hline 5 & $108.80 \pm 4.63$ & $30.19 \pm 2.87$ & $182.96 \pm 0.92$ & $298.15 \pm 1.85$ & $14.23 \pm 0.11$ & - & $57.56 \pm 0.55$ & $9.85 \pm 0.08$ \\
\hline 6 & $126.85 \pm 3.71$ & $41.39 \pm 3.64$ & $192.77 \pm 6.67$ & $123.61 \pm 9.25$ & $95.44 \pm 0.71$ & - & $41.84 \pm 0.74$ & $12.58 \pm 0.18$ \\
\hline 7 & $62.69 \pm 1.40$ & $38.06 \pm 3.10$ & $67.77 \pm 1.37$ & $47.04 \pm 1.50$ & $311.33 \pm 0.54$ & - & $176.87 \pm 0.72$ & $55.11 \pm 0.58$ \\
\hline 8 & $60.51 \pm 1.18$ & $38.98 \pm 4.76$ & $51.29 \pm 2.00$ & $30.19 \pm 2.43$ & $488.07 \pm 1.02$ & - & $199.70 \pm 0.99$ & $19.03 \pm 0.03$ \\
\hline 9 & $82.02 \pm 1.54$ & $37.87 \pm 0.94$ & $73.79 \pm 2.17$ & $65.37 \pm 7.52$ & $97.24 \pm 0.69$ & - & $151.23 \pm 0.73$ & $44.47 \pm 0.52$ \\
\hline \multirow[t]{2}{*}{ Trolox } & & & & & & & & $3.21 \pm 0.00$ \\
\hline & \multicolumn{4}{|c|}{$\operatorname{ABTS}\left(\mathrm{EC}_{50}\right)^{\mathrm{a}, \mathrm{b}, *} \mu \mathrm{g} / \mathrm{mL}$} & \multicolumn{4}{|c|}{$\beta$-Carotene bleaching $(\% \text { O.I })^{\mathrm{a}, \mathrm{d}}{ }^{*}$} \\
\hline Sample & $\mathrm{EtOH}$ & Hexane & EtOAc & $\mathrm{MeOH}: \mathrm{H}_{2} \mathrm{O}$ & $\mathrm{EtOH}$ & Hexane & EtOAc & $\mathrm{MeOH}: \mathrm{H}_{2} \mathrm{O}$ \\
\hline 1 & $32.44 \pm 0.22$ & $82.49 \pm 0.68$ & $15.42 \pm 0.15$ & $14.46 \pm 0.12$ & $79.42 \pm 2.09$ & $69.25 \pm 1.19$ & $80.70 \pm 3.83$ & $20.84 \pm 0.95$ \\
\hline 2 & $16.73 \pm 0.11$ & $98.79 \pm 0.33$ & $5.33 \pm 0.07$ & $4.62 \pm 0.06$ & $87.09 \pm 0.13$ & $33.19 \pm 0.32$ & $70.42 \pm 3.45$ & $43.47 \pm 1.21$ \\
\hline 3 & $21.23 \pm 0.20$ & $88.39 \pm 0.73$ & $11.56 \pm 0.10$ & $14.80 \pm 0.21$ & $83.26 \pm 2.50$ & $57.43 \pm 1.41$ & $75.08 \pm 1.50$ & $6.48 \pm 1.49$ \\
\hline 4 & $10.94 \pm 0.02$ & $74.65 \pm 0.26$ & $12.50 \pm 0.07$ & $16.18 \pm 0.07$ & $82.17 \pm 0.88$ & $53.29 \pm 0.87$ & $72.08 \pm 3.89$ & $45.76 \pm 1.74$ \\
\hline 5 & $14.82 \pm 0.04$ & $85.90 \pm 0.69$ & $7.65 \pm 0.09$ & $6.16 \pm 0.07$ & $73.86 \pm 0.34$ & $39.32 \pm 3.41$ & $78.85 \pm 0.79$ & $51.15 \pm 0.95$ \\
\hline 6 & $28.44 \pm 0.20$ & $100.14 \pm 0.73$ & $12.61 \pm 0.07$ & $10.80 \pm 0.13$ & $78.53 \pm 0.33$ & $40.21 \pm 1.21$ & $86.20 \pm 1.16$ & $40.78 \pm 2.95$ \\
\hline 7 & $44.36 \pm 0.41$ & $76.94 \pm 0.51$ & $12.99 \pm 0.10$ & $41.27 \pm 0.22$ & $61.60 \pm 1.68$ & $57.28 \pm 0.71$ & $75.53 \pm 2.95$ & $19.25 \pm 1.80$ \\
\hline 8 & $41.43 \pm 0.11$ & $67.36 \pm 0.58$ & $13.39 \pm 0.19$ & $13.57 \pm 0.13$ & $39.42 \pm 1.41$ & $28.31 \pm 1.40$ & $54.25 \pm 2.80$ & $39.18 \pm 0.26$ \\
\hline 9 & $27.44 \pm 0.18$ & $88.02 \pm 0.78$ & $13.76 \pm 0.08$ & $35.27 \pm 0.52$ & $69.77 \pm 1.05$ & $41.24 \pm 0.46$ & $81.92 \pm 1.12$ & $19.44 \pm 1.90$ \\
\hline Trolox & & & & & $95.02 \pm 0.29$ & $78.34 \pm 3.27$ & $95.02 \pm 0.30$ & $78.34 \pm 3.27$ \\
\hline
\end{tabular}

${ }^{a}$ Mean value \pm standard deviation: $\mathrm{n}=3$

${ }^{b}$ Concentration of antioxidant required to reduce the original amount of the radicals by $50 \%$.

${ }^{\mathrm{c}}$ No activity.

${ }^{\mathrm{d}}$ Oxidation inhibition.

*Differences were considered significant with $\mathrm{p}<0.05$

Table 3. Pearson correlation coefficients correlating total phenolic content with DPPH, ABTS and antioxidant methods

\begin{tabular}{lcc}
\hline Total phenolic content & DPPH & ABTS \\
\hline EtOH extract & -0.71 & -0.59 \\
Hexane fraction & - & - \\
EtOAc fraction & -0.88 & -0.73 \\
$\mathrm{MeOH}: \mathrm{H}_{2} \mathrm{O}$ fraction & -0.75 & -0.62 \\
\hline
\end{tabular}

\section{CONCLUSION}

The palynological analysis of nine $M$. mandacaia geopropolis from semiarid region indicated the presence 25 pollen types from 15 families. Senna (Leguminoseae) was the predominant pollen type in 8 of the 9 geopropolis. All geopropolis samples exhibited antioxidant activity, except to the hexane fraction that was inactive against DPPH radical. The present study demonstrated that the phenolic content of the mandaçaia geopropolis samples is responsible for their antioxidant activity, which supports the relevance of geopropolis as a rich source of bioactive compounds with potential health benefits.

\section{ACKNOWLEDGMENTS}

This study was financially supported by grants from CNPq (301935/2018-1, 462941/2014-0, and 425493/2018-0), FACEPE (Grant no. PRONEM APQ-0741106/2014), and CAPES. The authors also thank the CENAPESQ-UFRPE for the use of facilities. We express our special gratitude to the presidents of Brazil, Luiz Inacio Lula da Silva and Dilma Vana Rousseff, who have encouraged the development of scientific research in Brazil through the financial support of scientific projects.

\section{REFERENCES}

BANKOVA, V. S.; CASTRO, S. L.; MARCUCCI, M. C. Propolis: recent advances in chemistry and plant origin. Apidologie, 31: 3-15, 2000.

BARTH, O. M. Pollen analysis of Brazilian propolis. Grana. 37: 97-101, 1998. 
BARTH, O. M.; LUZ, F. P. Palynological analysis of Brazilian geopropolis sediments. Grana, 42: 121127, 2003.

CUNHA, M. G. et al. Antimicrobial and antiproliferative activities of stingless bee Melipona scutellaris geopropolis. BMC Complementary and Alternative Medicine, 13: 23, 2013.

DUTRA, R. P. et al. Phenolic acids, hydrolyzable tannins, and antioxidant activity of geopropolis from the stingless bee Melipona fasciculata Smith. Journal of Agricultural and Food Chemistry, 62: 2549-2557, 2014.

EMMONS, C. L.; PETERSON, D. M.; PAUL, G. L. Antioxidant capacity of oat (Avena sativa L.) extracts. 2 . In vitro antioxidant activity and contents of phenolic and tocol antioxidants. Journal of Agricultural and Food Chemistry, 47: 4894-4898, 1999.

ERDTMAN, G. The acetolysis method-a revised description. Sven Bot Tidskr, 54: 516-564, 1960.

FRANCHIN, M. et al. Geopropolis from Melipona scutellaris decreases the mechanical inflammatory hypernociception by inhibiting the production of IL$1 \beta$ and TNF- $\alpha$. Journal of Ethnopharmacology, 143: 709-715, 2012.

MATOS, V. R.; ALENCAR, S. M.; SANTOS, F. A. R. Pollen types and levels of total phenolic compounds in propolis produced by Apis mellifera L.(Apidae) in an area of the Semiarid Region of Bahia, Brazil. Anais da Academia Brasileira de Ciências, 86: 407-418, 2014.

PRIOR, R. L.; WU, X.; SCHAICH, K. Standardized methods for the determination of antioxidant capacity and phenolics in foods and dietary supplements. Journal of agricultural and food chemistry, 53: 4290-4302, 2005.

RE, R. et al. Antioxidant activity applying an improved ABTS radical cation decolorization assay. Free radical biology and medicine, 26: 1231-1237, 1999.

SANTOS, F. A. R. Identificação botânica do pólen apícola. Magistra, 23: 5-9, 2011.

SILVA, T. M. S. et al. Chemical composition and free radical scavenging activity of pollen loads from stingless bee Melipona subnitida Ducke. Journal of food composition and analysis, 19: 507-511, 2006.

SLINKARD, K.; SINGLETON, V. L. Total phenol analysis: automation and comparison with manual methods. American journal of enology and viticulture, 28: 49-55, 1977.

SOUZA JUNIOR, U. P. et al. Geopropolis gel for the adjuvant treatment of candidiasis - formulation and in vitro release assay. Revista Brasileira de Farmacognosia, 29: 278-286, 2019.

SOUZA, S. A. et al. Characterisation of phenolic compounds by UPLC-QTOF-MS/MS of geopropolis from the stingless bee Melipona subnitida (jandaíra). Phytochemical Analysis. 29: 549-558, 2018.

SOUZA, S. A. et al. Composition and antioxidant activity of geopropolis collected by Melipona subnitida (Jandaíra) bees. Evidence-Based Complementary and Alternative Medicine, v. 2013, 2013.

TOMÁS-BARBERÁN, F. A. et al. Phytochemical evidence for the botanical origin of tropical propolis from Venezuela. Phytochemistry, 34: 191-196, 1993.

VELIKOVA, M. et al. Chemical composition and biological activity of propolis from Brazilian meliponinae. Zeitschrift für Naturforschung C, 55: 785-789, 2000. 